\title{
Dynamics of Nitrogen Transformations in the Soil Fertilized with Digestate from Agricultural Biogas Plant
}

\section{Agnieszka Wysocka-Czubaszek ${ }^{1}$}

1 Department of Agri-Food Engineering and Environmental Management, Faculty of Civil and Environmental Engineering, Białystok University of Technology, ul. Wiejska 45A, 15-351 Białystok, Poland

e-mail: a.wysocka@pb.edu.pl

\begin{abstract}
The biogas production from dedicated crops creates an additional organic fertilizer which may, at least partially, substitute synthetic- $\mathrm{N}$ fertilizers. The digestates are characterized by an elevated $\mathrm{NH}_{4}-\mathrm{N}$ content; therefore, they may supply more readily-available $\mathrm{N}$ to the crops, compared to manures. Thus, the aim of the study was the analysis of $\mathrm{N}$ dynamics in the soil fertilized with the digestate from agricultural biogas plant fed mainly with maize silage with addition of poultry manure and potato pulp. A laboratory incubation experiment was conducted for 56 days and the soil was sampled from the field fertilized with the same digestate under the conditions of regular farming practices. In both the incubation experiment and the field study, the digestate supplied the soil in $\mathrm{NH}_{4}-\mathrm{N}$. The inorganic-N transformation showed a similar overall pattern with some differences. In the incubation experiment, after the application of the digestate in the amount corresponding to the fertilizer dose of $170 \mathrm{~kg} \mathrm{~N}^{-1}$, the $\mathrm{NH}_{4}-\mathrm{N}$ content decreased rapidly during the first 14 days from $61.54 \pm 5.65 \mathrm{mg} \mathrm{N} \mathrm{kg}^{-1}$ to $19.02 \pm 4.12 \mathrm{mg} \mathrm{N} \mathrm{kg}^{-1}$ and then at the day 42 - to values close to zero. In contrast, the $\mathrm{NO}_{3}-\mathrm{N}$ content increased from $6.35 \pm 0.35 \mathrm{mg} \mathrm{N} \mathrm{kg}^{-1}$ to $50.65 \pm 4.73 \mathrm{mg} \mathrm{N} \mathrm{kg}^{-1}$ at day 14 and further to $79.06 \pm 13.95 \mathrm{mg} \mathrm{N} \mathrm{kg}^{-1}$ at day 42 . In the field, the elevation of the $\mathrm{NH}_{4}-\mathrm{N}$ content after digestate application was less pronounced as a consequence of lower application rate $(114 \mathrm{~kg}$ $\mathrm{N} \mathrm{ha}^{-1}$ ); however, the rapid drop in the ammonium- $\mathrm{N}$ content from $20.41 \pm 9.18 \mathrm{mg} \mathrm{N} \mathrm{kg}^{-1}$ at day 0 to $14.80 \pm 9.75 \mathrm{mg}$ $\mathrm{N} \mathrm{kg}^{-1}$ at day 7 followed by a slow decrease until the day 56, was observed. The average soil $\mathrm{NO}_{3}-\mathrm{N}_{\text {content was }}$ rather constant in the first 7 days after fertilization and the rapid nitrification occurred in next 49 days resulting in the nitrate- $\mathrm{N}$ increase to $32.97 \pm 24.46 \mathrm{mg} \mathrm{N} \mathrm{kg}^{-1}$. The overall pattern of $\mathrm{N}$ dynamics in the soil fertilized with digestate was the same in the incubation experiment and under the field condition, even though the studied soils showed some dissimilarities. Rapid ammonium-N transformation to nitrate-N may create favourable conditions for nitrate leaching; therefore, the farm management techniques should be focused on nutrient recycling and $\mathrm{N}$ loss prevention.
\end{abstract}

Keywords: digestate, inorganic nitrogen, nitrification

\section{INTRODUCTION}

Digestate, as a by-product of anaerobic digestion (AD) of organic matter during biogas production, is a valuable fertilizer with an increased content of $\mathrm{NH}_{4}-\mathrm{N}$ comparing to substrates. During anaerobic digestion, total nitrogen (TN) is conserved, while complex organic $\mathrm{N}$ compounds are mineralized to the ammonium form, which is used by microorganisms in the digester only partially. Less than $1 \%$ of $\mathrm{TN}$ is lost during the $\mathrm{AD}$ process as a result of struvite and ammonium carbonate formation and $\mathrm{N}$ volatilization in the biogas stream [Möller, Müller 2012].
Addition of nitrogen with digestate to soil causes many processes such as mineralization, immobilization, nitrification and denitrification, together with leaching and volatilization, which depend not only on the intrinsic properties of digestate such as the content and form of applied $\mathrm{N}$ but also on soil properties, weather conditions, mainly temperature and precipitation and application technology. The mineralization and nitrification rate depends mainly on organic matter (OM) content in the soil and to some extent on soil textural properties; however, the interaction with clay minerals is less significant [Rigby, Smith 2013]. The digestate type, depending on 
raw material used for $\mathrm{AD}$ process, also affects the rate of nitrogen transformation and introduction liquid or solid fraction may promote or suppress the $\mathrm{N}$ mineralization [de la Fuente et al. 2013]. The digestate stability influences the $\mathrm{N}$-dynamics in soil; therefore, not all digested materials can be applied directly to the field, some less stable ones should undergo curing or maturing process first and highly unstable materials should be stabilized by means of the aerobic post-treatment [Alburquerque et al. 2012].

Most studies on the $\mathrm{N}$ dynamics in soil after application of digestate are based on the incubation experiments carried out under controlled conditions which allow eliminating weather conditions, plant uptake and spatial heterogeneity of soil changing in time [Delin et al. 2012]. Incubation experiments are often carried out in soil moisture adjusted to $60 \%$ water holding capacity and the temperature of $25^{\circ} \mathrm{C}$, which are the optimal conditions for mineralization and nitrification process [Smith et al. 1998] but rather unlikely to be found and last for several weeks in the field, especially in the countries with temperate or cold climate. This could be overcome by the temperature adjustment to the real mean temperature of the vegetation period [Johansen et al. 2013], but this, in turn, may complicate the comparison of the results. The field trails are conducted under the local weather conditions, often with the crop rotation typical for the region. Even though the weather and - hence - the soil moisture and temperature variability as well as soil heterogeneity may have some impact on the results. Nevertheless, Cavalli et al. [2017] reported that the N availability in the soil fertilized with manure and digestate in the incubation experiment and field trials were similar but the incubation method gave better insights into the decomposition dynamics.

The aim of the study was to analyze the $\mathrm{N}$ dynamics in the soil fertilized with the digestate from agricultural biogas plant fed mainly with maize silage with addition of poultry manure and potato pulp. Additionally, the results from the incubation method were compared with the results obtained from sampling soil under regular cultivation.

\section{METHODS}

\section{The incubation experiment}

A loamy sandy soil used in the incubation experiment was collected from $0-0.2 \mathrm{~m}$ depth of ar- able field at the organic farm located in the vicinity of Białystok (53 $3^{\circ} 17^{\prime} \mathrm{N}, 23^{\circ} 11^{\prime} \mathrm{E}, 147 \mathrm{~m}$ a.s.1.). The textural and chemical characteristics of the soil are shown in Table 1. Prior to the incubation, the soil was air dried and passed through a $2 \mathrm{~mm}$ sieve. The digestate (MSD) used in the incubation experiment was obtained from agricultural mesophilic biogas plant fed with maize silage $(90 \%)$, poultry manure $(5 \%)$ and potato pulp $(5 \%)$. The main digestate properties are presented in Table 2.

The aerobic incubation of $77 \mathrm{~g}$ ww of soil treated with digestate was performed in the dark for 56 days at temperature $25 \pm 1{ }^{\circ} \mathrm{C}$ in three replicates. The soil moisture was adjusted to $60 \%$ of the water holding capacity (WHC). Fresh digestate was added to the soil in the amount equal to the recommended annual rate of $\mathrm{N}$ application in organic fertilizers, which is $170 \mathrm{~kg} \mathrm{~N} \mathrm{ha}^{-1}$ [Journal of Laws of 2007 No. 147 item 1033]. The exact rate was calculated on the basis of the nitrogen content in digestate and measured bulk density of soil equal to $1.51 \mathrm{~g} \mathrm{~cm}^{-3}$ assuming the cultivation depth of $0.2 \mathrm{~m}$. The soil was incubated in plastic vessels of $100 \mathrm{ml}$ capacity and covered with Parafilm to control the soil moisture and to ensure correct diffusion of gases. The soil moisture was checked every 3-4 days and adjusted by adding distilled water if necessary. In order to follow the $\mathrm{N}$ dynamics, three samples were removed from the incubator at day $0,2,7,14,28$, 42 and 56 for the analysis of inorganic nitrogen $\left(\mathrm{NO}_{3}-\mathrm{N}\right.$ and $\left.\mathrm{NH}_{4}-\mathrm{N}\right)$. Additionally, total $\mathrm{N}$, soil organic $\mathrm{C}, \mathrm{pH}$ and electrical conductivity (EC) were measured. The samples without the addition of digestate were treated as control. In total, 42 samples were incubated.

\section{The field study}

The field study was carried out on the arable field located in the vicinity of Białystok $\left(52^{\circ} 92^{\prime} \mathrm{N}\right.$, $23^{\circ} 24^{\prime} \mathrm{E}, 140 \mathrm{~m}$ a.s.1.). The climate of the region is classified as temperate with certain features of thermal continentalism, with short vegetation period lasting from 190 to 200 days, warm summers and cold winters. The annual precipitation averages $593 \mathrm{~mm}$ and the average air temperature is $6.8^{\circ} \mathrm{C}$ (Górniak 2000). The field is cultivated with conventional system with digestate as fertilizer and crop rotation consisting of triticale (Triticosecale Wittm. Ex A. Camus.) and maize (Zea mays L.). The digestate used as fertilizer was obtained from the same agricultural biogas plant. 
Table 1. Main characteristics of the soil used for the incubation experiment and the soil in the studied field

\begin{tabular}{|c|c|c|}
\hline Parameter & $\begin{array}{c}\text { Soil used for incubation } \\
\text { experiment }\end{array}$ & Soil in the studied field \\
\hline Sand $(\%)$ & 83 & 73 \\
\hline Silt (\%) & 16 & 23 \\
\hline Clay (\%) & 1 & 1 \\
\hline $\mathrm{pH}_{\mathrm{KCl}}$ & $4.75 \pm 0.12$ & $4.35 \pm 0.17$ \\
\hline Electrical conductivity EC $\left(\mu \mathrm{S} \mathrm{sm}^{-1}\right)$ & $55.33 \pm 2.04$ & $77.46 \pm 12.68$ \\
\hline $\mathrm{NO}_{3}-\mathrm{N}\left(\mathrm{mg} \mathrm{kg}^{-1}\right)$ & $2.85 \pm 0.23$ & $3.02 \pm 1.75$ \\
\hline $\mathrm{NH}_{4}-\mathrm{N}\left(\mathrm{mg} \mathrm{kg}^{-1}\right)$ & $27.98 \pm 0.98$ & $6.91 \pm 2.68$ \\
\hline Total $\mathrm{N}\left(\mathrm{g} \mathrm{kg}^{-1}\right)$ & $0.90 \pm 0.02$ & $0.91 \pm 0.07$ \\
\hline Organic $\mathrm{C}\left(\mathrm{g} \mathrm{kg}^{-1}\right)$ & $15.46 \pm 1.08$ & $7.30 \pm 0.81$ \\
\hline $\mathrm{C}: \mathrm{N}$ & 16 & 8 \\
\hline Available $\mathrm{P}\left(\mathrm{mg} \mathrm{kg}^{-1}\right)$ & $76.53 \pm 4.04$ & $108.09 \pm 8.58$ \\
\hline Available $\mathrm{K}\left(\mathrm{mg} \mathrm{kg}^{-1}\right)$ & $90.64 \pm 2.57$ & $149.57 \pm 21.64$ \\
\hline Total P $\left(\mathrm{g} \mathrm{kg}^{-1}\right)$ & $0.86 \pm 0.06$ & $0.68 \pm 0.03$ \\
\hline Total $\mathrm{K}\left(\mathrm{g} \mathrm{kg}^{-1}\right)$ & $1.01 \pm 0.04$ & $2.62 \pm 0.22$ \\
\hline \multicolumn{3}{|l|}{ Base cations } \\
\hline $\mathrm{Ca}^{2+}\left(\mathrm{cmol}(+) \mathrm{kg}^{-1}\right)$ & $2.60 \pm 0.00$ & $1.56 \pm 0.36$ \\
\hline $\mathrm{Mg}^{2+}\left(\mathrm{cmol}(+) \mathrm{kg}^{-1}\right)$ & $1.07 \pm 0.31$ & $0.20 \pm 0.07$ \\
\hline $\mathrm{K}^{+}\left(\mathrm{cmol}(+) \mathrm{kg}^{-1}\right)$ & $0.37 \pm 0.00$ & $0.32 \pm 0.06$ \\
\hline $\mathrm{Na}^{+}\left(\mathrm{cmol}(+) \mathrm{kg}^{-1}\right)$ & $0.06 \pm 0.00$ & $0.05 \pm 0.05$ \\
\hline Sum of base cations SBC $\left(\mathrm{cmol}(+) \mathrm{kg}^{-1}\right)$ & $4.09 \pm 0.30$ & $2.13 \pm 0.48$ \\
\hline Hydrolityc acidity $\mathrm{HA}\left(\mathrm{cmol}(+) \mathrm{kg}^{-1}\right)$ & $3.45 \pm 0.52$ & $2.71 \pm 0.46$ \\
\hline Cation exchange capacity CEC $\left(\mathrm{cmol}(+) \mathrm{kg}^{-1}\right)$ & $7.54 \pm 0.34$ & $4.83 \pm 0.32$ \\
\hline Base saturation BS (\%) & $54.37 \pm 5.15$ & $43.93 \pm 9.38$ \\
\hline
\end{tabular}

Table 2. Main characteristics of the digestate used for the incubation experiment and as the fertilizer in the field study

\begin{tabular}{|l|c|c|}
\hline \multicolumn{1}{|c|}{ Parameter } & Digestate used for incubation experiment & Digestate used on the studied field \\
\hline Total solids $(\%)$ & $7.21 \pm 0.13$ & $6.42 \pm 0.10$ \\
\hline Volatile solids $(\% T S)$ & $72.59 \pm 0.28$ & $76.67 \pm 0.51$ \\
\hline Total Kjeldahl N $\left(\mathrm{g} \mathrm{kg}^{-1} \mathrm{DM}\right)$ & $61.48 \pm 3.08$ & $60.07 \pm 2.18$ \\
\hline Total organic C $\left(\mathrm{g} \mathrm{kg}^{-1} \mathrm{DM}\right)$ & $389.55 \pm 12.1$ & $416.86 \pm 29.8$ \\
\hline Total P $\left(\mathrm{g} \mathrm{kg}^{-1} \mathrm{DM}\right)$ & $11.81 \pm 0.30$ & $8.03 \pm 0.73$ \\
\hline Total K $\left(\mathrm{g} \mathrm{kg}^{-1} \mathrm{DM}\right)$ & $49.96 \pm 1.16$ & $49.35 \pm 3.24$ \\
\hline
\end{tabular}

The main characteristics of the digestate are shown in Table 2, while the textural and chemical characteristics of the soil are presented in Table 1. In August 2015 after triticale harvest, the field was fertilized with the digestate in application dose of $30 \mathrm{~m}^{3} \mathrm{ha}^{-1}$ (corresponding to $114 \mathrm{~kg} \mathrm{~N}$ $\mathrm{ha}^{-1}$ ), then the digestate was incorporated into the soil with disk harrow. The soil samples in 10 replicates were collected on the following occasions: after triticale harvest; after digestate incorporation into the soil at day 0 , and then 5, 7, 40 and 56 days after fertilization. The $\mathrm{NO}_{3}-\mathrm{N}$ and $\mathrm{NH}_{4}-\mathrm{N}$ content in the samples was measured. In addition, the $\mathrm{pH}, \mathrm{EC}, \mathrm{TN}$ and SOC were determined.

The daily precipitation and temperature data for period from June to October 2015 were taken from WatchDog 2900ET weather station located at the Białystok University of Technology.

\section{Analytical methods}

The soil moisture was determined after drying at $105 \pm 2^{\circ} \mathrm{C}$ to constant weight. The soil particle-size distribution was assessed according to the Bouyoucos method modified by Casagrande and Prószyński. Bulk density was assessed in undisturbed soil samples in steal cylinder with volume of $100 \mathrm{~cm}^{3}$. The soil $\mathrm{pH}_{\mathrm{KCl}}$ was determined with a HQD $40 \mathrm{pH}$ meter (Hach, USA) in 1:2.5 $(\mathrm{w} / \mathrm{v}$ as $\mathrm{g} / \mathrm{ml}$ ) soil/0.1 $\mathrm{M} \mathrm{KCl}$ suspension. The soil EC was measured with HQD 40 meter (Hach, USA) in 1:2.5 (w/v as $\mathrm{g} / \mathrm{ml})$ soil/water suspen- 
sion. The concentrations of $\mathrm{NH}_{4}-\mathrm{N}$ and $\mathrm{NO}_{3}-\mathrm{N}$ were measured by means of UV-1800 spectrophotometer (Shimadzu, Japan) in filtrates of 1\% $\mathrm{K}_{2} \mathrm{SO}_{4}$. Organic carbon was measured in TOC-L analyser with SSM-5000A Solid Sample Combustion Unit (Shimadzu, Japan). Total nitrogen (TN) was determined with the Kjeldahl method in Vapodest 50s analyzer (Gerhardt, Germany). Hydrolytic acidity (HA) was measured by means of Kappen method, base cations were extracted with $1 \mathrm{M}$ ammonium acetate, magnesium and calcium were measured with flame AAS (Avanta PM, GBC Scientific Equipment Pty Ltd, Australia), sodium and potassium were determined using flame photometry (BWB Technology, UK). The sum of base cations (SBC), cation exchange capacity (CEC) and base saturation (BS) were calculated. After extraction with calcium lactate solution, the plant-available $\mathrm{P}$ was determined with ammonium metavanadate method using UV-1800 spectrophotometer (Shimadzu, Japan) and plant available $\mathrm{K}$ was analyzed using flame photometry (BWB Technology, USA). After nitric acid/hydrogen peroxide microwave digestion in ETHOS One (Milestone s.r.l., Italy) the content of total $\mathrm{P}$ was determined with ammonium metavanadate method using UV-1800 spectrophotometer (Shimadzu, Japan) and the total $\mathrm{K}$ content was measured using flame photometry (BWB Technology, USA).

Total solids (TS) and volatile solids (VS) in the digestates were measured according to the standard methods [APHA 1998]. The digestates were analyzed for total Kjeldahl nitrogen (TKN), total organic carbon (TOC), total $\mathrm{P}$ and $\mathrm{K}$ with methods used for determination of these parameters in soil. The analyses of soil and organic materials were run in triplicate.

\section{Statistical analysis}

The data from incubation experiment were subjected to two-way analysis of variance (ANOVA) and the difference between means was determined by Tukey HSD test $(\mathrm{p}<0.05)$. The Kruskal-Wallis test was performed on the data from the field study, because of the inhomogeneity of results obtained from chemical analyses. The comparison of digestates and soils used for incubation and from the studied field was performed using U Mann-Whitney test $(p<0.05)$. All analyses were conducted using Statistica 12 software.

\section{RESULTS AND DISCUSSION}

Both soils were loamy sands with $\mathrm{pH}_{\mathrm{KCl}}$ indicating acidic conditions. The $\mathrm{NO}_{3}-\mathrm{N}$ concentration in the soil for incubation was lower than in the soil from field, while the soil used for the incubation experiment was characterized with much higher $(\mathrm{p}<0.05) \mathrm{NH}_{4}-\mathrm{N}$ content equal to $27.98 \pm 0.98 \mathrm{mg} \mathrm{N} \mathrm{kg}^{-1}$ comparing to soil from the field $\left(6.91 \pm 2.68 \mathrm{mg} \mathrm{N} \mathrm{kg}^{-1}\right)$. The TN content was very similar in both soils, while SOC was significantly higher $(\mathrm{p}<0.05)$ in the soil used for incubation experiment, which resulted in a better $\mathrm{C} / \mathrm{N}$ ratio in this soil. The soil from the studied field was characterized with significantly higher $(\mathrm{p}<0.05)$ content of plant-available $\mathrm{P}$ and $\mathrm{K}$. The total $\mathrm{P}$ content was higher in the soil taken for incubation, while the total $\mathrm{K}$ content was higher in the soil from the studied field. Additionally, SBC and CEC were significantly $(\mathrm{p}<0.05)$ higher in the soil used for incubation. The differences between the soil properties are mainly due to the different farming system. The soils under organic farming system are usually characterized with higher $\mathrm{pH}$ values and lower nitrate content but higher nutrient mineralization potential and higher SOC content than the soils under conventional farming system [Schrama et al. 2018]. Higher SOC concentration and stocks in the top part of soil under organic farming system are mainly due to the organic matter recycling and incorporation of forage legumes in crop rotation [Gattinger et. al. 2012]. Low content of the plant-available $P$ is also typical for the soils under organic farming system and is the result of soil depletion through nutrient removal with crops and addition of nutrients in organic or slow-release sources, therefore not containing readily soluble nutrients [Stockdale et al. 2002].

Both digestates originated from the same biogas plant; thus, all measured parameters were similar. Total solids were equal to $7.21 \pm 0.13 \%$ and $6.42 \pm 0.10 \%$, while volatile solids amounted to $72.59 \pm 0.28 \%$ TS and $76.67 \pm 0.51 \%$ TS, typical for digestate obtained from maize silage [Malerba et al. 2014]. The TKN content was similar in the samples taken for both occasions and was in good agreement with the results obtained for the digestate produced in agricultural biogas plant fed with similar substrates [Malerba et al. 2014]. Only the TP content was higher $\left(11.81 \pm 0.30 \mathrm{~g} \mathrm{~kg}^{-1}\right)$ in the digestate used for the incubation experiment than in the digestate used for field fertilization 
$\left(8.03 \pm 0.73 \mathrm{~g} \mathrm{~kg}^{-1}\right)$, however the difference was not statistically significant ( $\mathrm{p}>0.05$ ).

In the incubation test, the addition of the digestate resulted in an elevation of ammonium- $\mathrm{N}$ content from $14.86 \pm 0.60 \mathrm{mg} \mathrm{N} \mathrm{kg}^{-1}$ to $61.54 \pm 5.65 \mathrm{mg}$ $\mathrm{N} \mathrm{kg}^{-1}$ at day 0 , while the $\mathrm{NO}_{3}-\mathrm{N}$ content was low and amounted to $6.35 \pm 0.35 \mathrm{mg} \mathrm{N} \mathrm{kg}{ }^{-1}$. The elevated concentration of $\mathrm{NH}_{4}-\mathrm{N}$ in the soil treated with the digestate resulted from nitrogen occurrence mainly in the ammonium form as a consequence of organic- $\mathrm{N}$ mineralization during the AD process [Möller, Müller 2012]. In the control soil, the $\mathrm{NH}_{4}-\mathrm{N}$ content decreased rapidly during the first 7 days of incubation to $5.15 \pm 2.18 \mathrm{mg} \mathrm{N}$ $\mathrm{kg}^{-1}$ and a slower decline to $2.91 \pm 1.17 \mathrm{mg} \mathrm{N} \mathrm{kg}^{-1}$ was observed in next 7 days. After next two weeks, the amount of ammonium- $\mathrm{N}$ in control soil increased slightly to $7.60 \pm 3.41 \mathrm{mg} \mathrm{N} \mathrm{kg}^{-1}$ and from day 42 onward, its concentration was close to zero (Figure 1a). Similar pattern of $\mathrm{NH}_{4}$ $\mathrm{N}$ content was observed in the soil fertilized with digestate; however, the amounts of ammonium-N in soil were much higher. The $\mathrm{NH}_{4}-\mathrm{N}$ concentration rapidly declined within the first two weeks and was equal to $19.02 \pm 4.12 \mathrm{mg} \mathrm{N} \mathrm{kg}^{-1}$ at day 14 , and then fertilized soil showed a fairly constant $\mathrm{NH}_{4}-\mathrm{N}$ content until the day 42, when it dropped down to almost zero and stayed at this level till the end of incubation. This pattern of $\mathrm{NH}_{4}-\mathrm{N}$ dynamics during the incubation experiments conducted on soils amended with digestates originated from $\mathrm{AD}$ process of different substrates and treated with organic fertilizers was reported previously

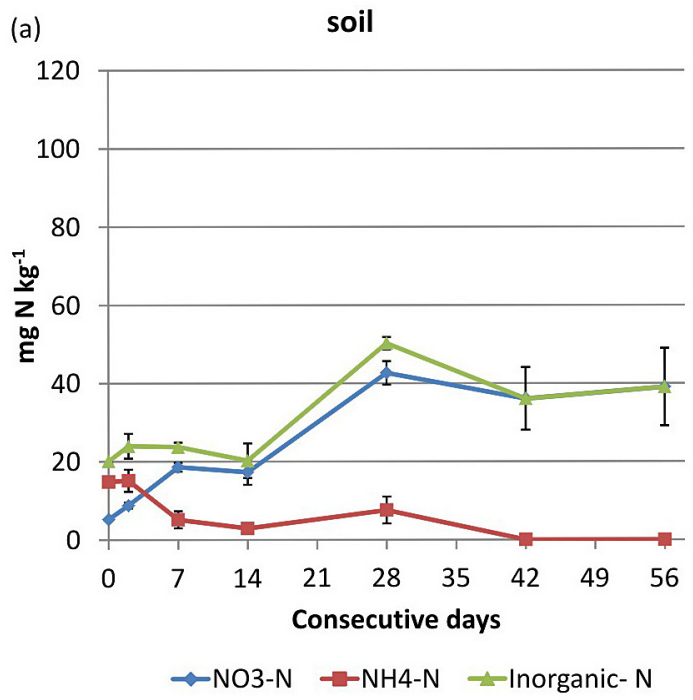

[Alburquerque et al. 2012, Gómez-Brandón et al. 2016, Wysocka-Czubaszek et al. 2018].

In contrast, the $\mathrm{NO}_{3}-\mathrm{N}$ content in both soils was low at the beginning of the experiment and amounted to $5.23 \pm 0.30 \mathrm{mg} \mathrm{N} \mathrm{kg}^{-1}$ in the control soil and to $6.35 \pm 0.35 \mathrm{mg} \mathrm{N} \mathrm{kg}^{-1}$ in the fertilized soil. The unamended soil showed an increase of $\mathrm{NO}_{3}-\mathrm{N}$ content until day 7 to the value of $18.60 \pm 1.14 \mathrm{mg} \mathrm{N} \mathrm{kg}^{-1}$ and then showed a fairly constant $\mathrm{NO}_{3}-\mathrm{N}$ content during next 7 days. In the next two weeksm the $\mathrm{NO}_{3}-\mathrm{N}$ concentration rose to $42.56 \pm 3.01 \mathrm{mg} \mathrm{N} \mathrm{kg}^{-1}$ and further was fairly stable till the end of incubation at day 56. In the soil treated with digestate, a rapid increase of the $\mathrm{NO}_{3}-\mathrm{N}$ content to the value of $50.65 \pm 4.73 \mathrm{mg} \mathrm{N} \mathrm{kg}^{-1}$ was observed in the first two weeks of incubation and slower but constant nitrification until day 42 to the highest value of $79.06 \pm 13.95 \mathrm{mg} \mathrm{N} \mathrm{kg}^{-1}$ (Figure 1b). The main effects of the time and addition of digestate were statistically significant $(p<0.001)$ for the inorganic- $\mathrm{N}$ content in soil. A rapid decrease of $\mathrm{NH}_{4}-\mathrm{N}$ content with a concomitant rise of $\mathrm{NO}_{3}-\mathrm{N}$ concentration observed in the incubation experiment indicates the nitrification process [Goberna et al. 2011], while the losses of $\mathrm{NH}_{4}^{+}$in the process of ammonia volatilization is more unlikely because the digestate was mixed with soil immediately after application [de la Fuente et al. 2010]. At the end of incubation, very low $\mathrm{NH}_{4}-\mathrm{N}$ content created the conditions for microbial assimilation of $\mathrm{NO}_{3}^{-}$[Myrold, Posavatz 2007] which resulted in a decrease of inorganic-N content at day 56 .

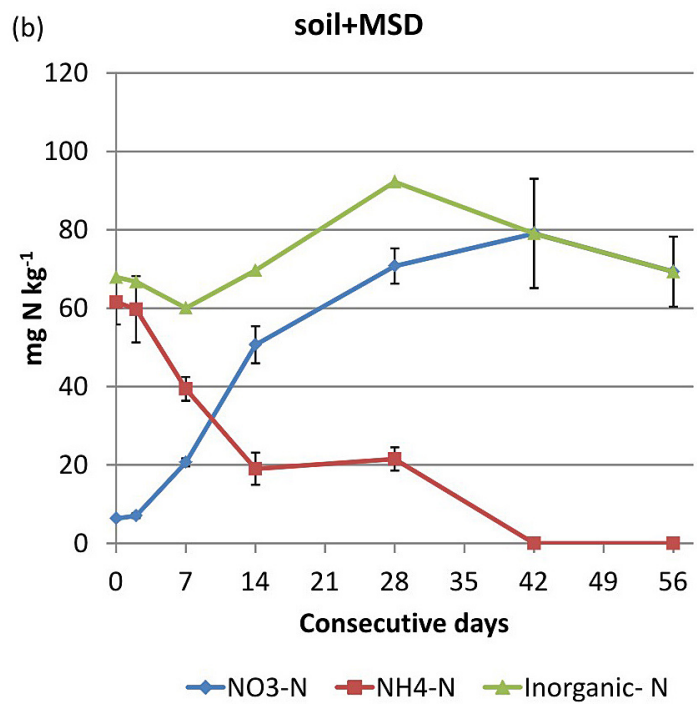

Figure 1. Changes in $\mathrm{NO}_{3}-\mathrm{N}, \mathrm{NH}_{4}-\mathrm{N}$ and inorganic-N content in control soil (a) and in soil treated with digestate (b) in the incubation experiment 
The $\mathrm{pH}_{\mathrm{KCl}}$ in both unamended and amended soils was acidic and decreased very slightly; however, the decline in the soil treated with digestate was more pronounced (Figure 2a). The soil $\mathrm{pH}$ was significantly influenced both by time and addition of digestate $(p<0.001)$ and paralleled nitrification process due to acidifying effect of proton formation [Bernal, Kirchmann 1992]. These results are consistent with the studies on $\mathrm{N}$ transformation in the soils treated with raw cattle slurry and cattle slurry co-digested with maize silage or grass-clover silage [Johansen et al. 2013]. The EC mirrored the pattern observed for $\mathrm{NO}_{3}-\mathrm{N}$ content. In the soil control, the $\mathrm{EC}$ value at day 0 was equal to $55.0 \pm 2.0 \mu \mathrm{S} \mathrm{cm}^{-1}$ and rose to $167.4 \pm 0.9 \mu \mathrm{S} \mathrm{cm}^{-1}$ at the end of incubation, while in the soil treated with digestate, the increase of soil EC was observed from $80.1 \pm 0.5 \mu \mathrm{S} \mathrm{cm}^{-1}$ at day 0 after fertilizer application to $285.7 \pm 9.5 \mu \mathrm{S} \mathrm{cm}^{-1}$ at day 56 (Fig. 2b). Soil EC was influenced by time $(p<0.001)$, addition of digestate $(p<0.001)$ and their interactions $(p<0.001)$. A similar pattern of EC dynamics in soil was observed by GómezBrandón et al. [2016]; however, the EC values were much higher in the control soil and in the soil treated with manure, compost, vermicompost and digestate than in the present study. The differences in the obtained results are mainly due to the significantly lower EC value in the soil used in the present experiment.

The total nitrogen content was similar in both control and fertilized soil and was equal to $1.05 \pm 0.04 \mathrm{~g} \mathrm{~N} \mathrm{~kg}^{-1}$. At the end of incubation, the TN content was very similar and amounted

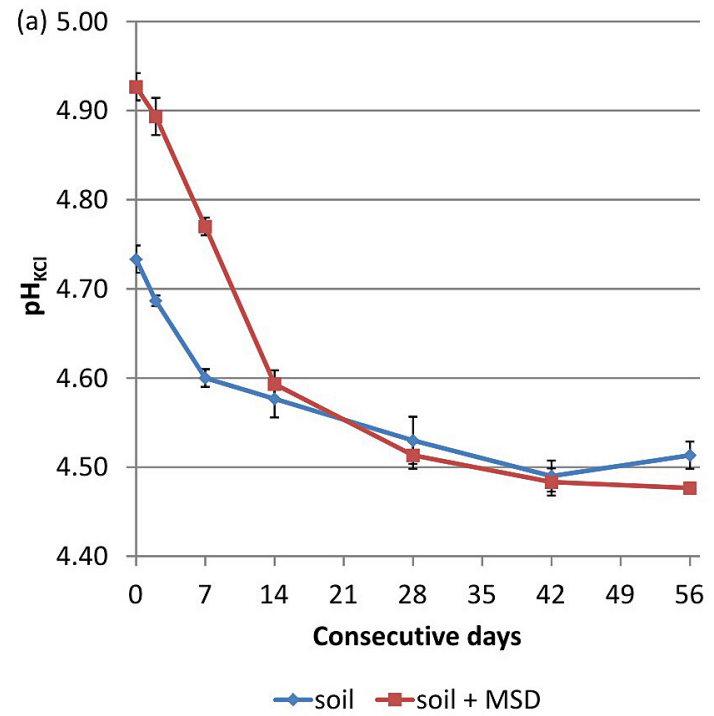

to $1.05 \pm 0.01 \mathrm{~g} \mathrm{~N} \mathrm{~kg}^{-1}$ and $1.06 \pm 0.02 \mathrm{~g} \mathrm{~N} \mathrm{~kg}^{-1}$ in the control and amended soil, respectively (Figure 3a). The soil organic carbon in the control soil was equal to $15.28 \pm 0.27 \mathrm{~g} \mathrm{C} \mathrm{kg}^{-1}$ and was similar in the fertilized soil. After 56 days of incubation, the SOC content was still on the same level (Figure 3b).

The nitrification process under the conditions of regular soil fertilization in the field under local weather conditions followed similar pattern. The digestate used as fertilizer on the studied field supplied the soil in ammonium-N, the content of which in soil increased significantly $(\mathrm{p}<0.05)$ from $6.91 \pm 2.68 \mathrm{mg} \mathrm{N} \mathrm{kg}^{-1}$ to $20.41 \pm 9.18 \mathrm{mg} \mathrm{N} \mathrm{kg}^{-1}$. In next 5 days slight increase of the $\mathrm{NH}_{4}-\mathrm{N}$ content was observed and a rapid decline in next 2 days occurred to the value of $14.80 \pm 9.75 \mathrm{mg} \mathrm{N} \mathrm{kg}^{-1}$. In next 49 days the $\mathrm{NH}_{4}-\mathrm{N}$ content decreased very slowly to the value of $4.86 \pm 2.76 \mathrm{mg} \mathrm{N} \mathrm{kg}^{-1}$. The soil $\mathrm{NO}_{3}-\mathrm{N}$ content was rather constant in the first 7 days after fertilization and the rapid nitrification occurred in next 49 days resulting in significant $(\mathrm{p}<0.05)$ nitrate- $\mathrm{N}$ increase to $32.97 \pm 24.46 \mathrm{mg} \mathrm{N} \mathrm{kg}^{-1}$ (Figure 4a). Incorporation of digestate into the soil resulted in an increase of the $\mathrm{NH}_{4}-\mathrm{N}$ content and started several processes such as nitrification, immobilization and emission. Very low moisture of soil $4.23 \pm 1.00 \%$ (Figure $4 \mathrm{~b}$ ) at the day of digestate application and incorporation to the soil, created unfavourable conditions for denitrification and for ammonia volatilization; thus, it seemed that the main process occuring in the soil was nitrification, as it was observed by Goberna et al.

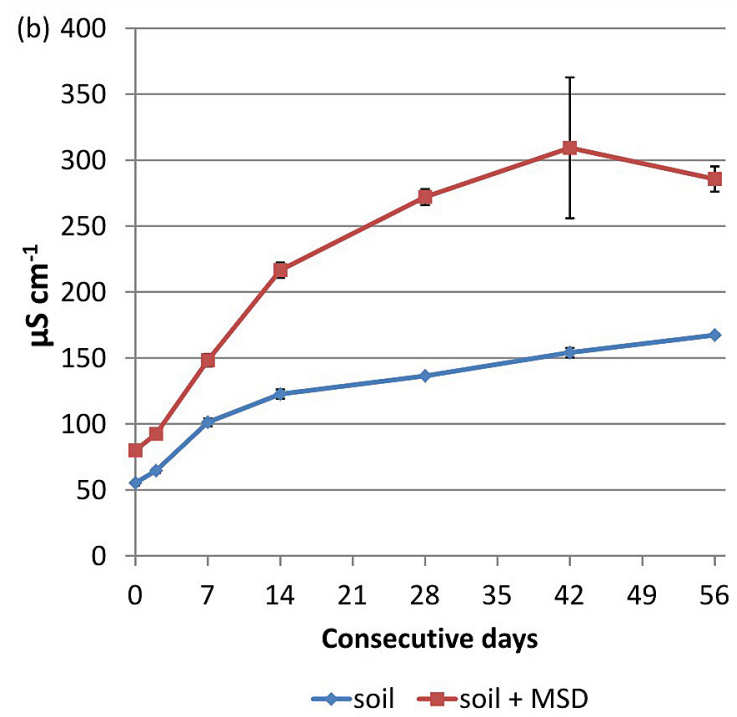

Figure 2. Changes in $\mathrm{pH}_{\mathrm{KCl}}$ (a) and $\mathrm{EC} \mathrm{(b)} \mathrm{in} \mathrm{control} \mathrm{soil} \mathrm{and} \mathrm{soil} \mathrm{treated} \mathrm{with} \mathrm{digestate} \mathrm{in} \mathrm{incubation} \mathrm{experiment}$ 

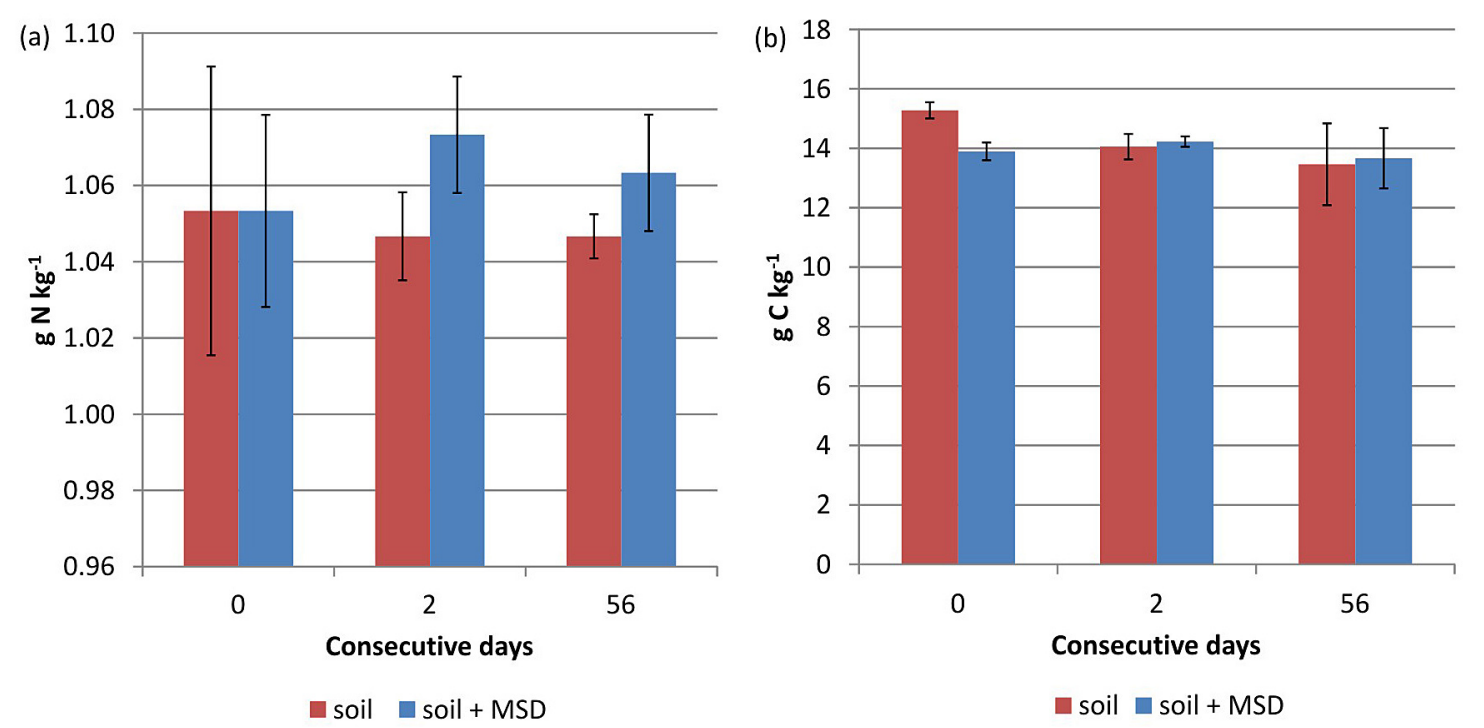

Figure 3. Total nitrogen content (a) and soil organic carbon content (b) at the beginning (day 0) and at the end (day 56) of the incubation experiment
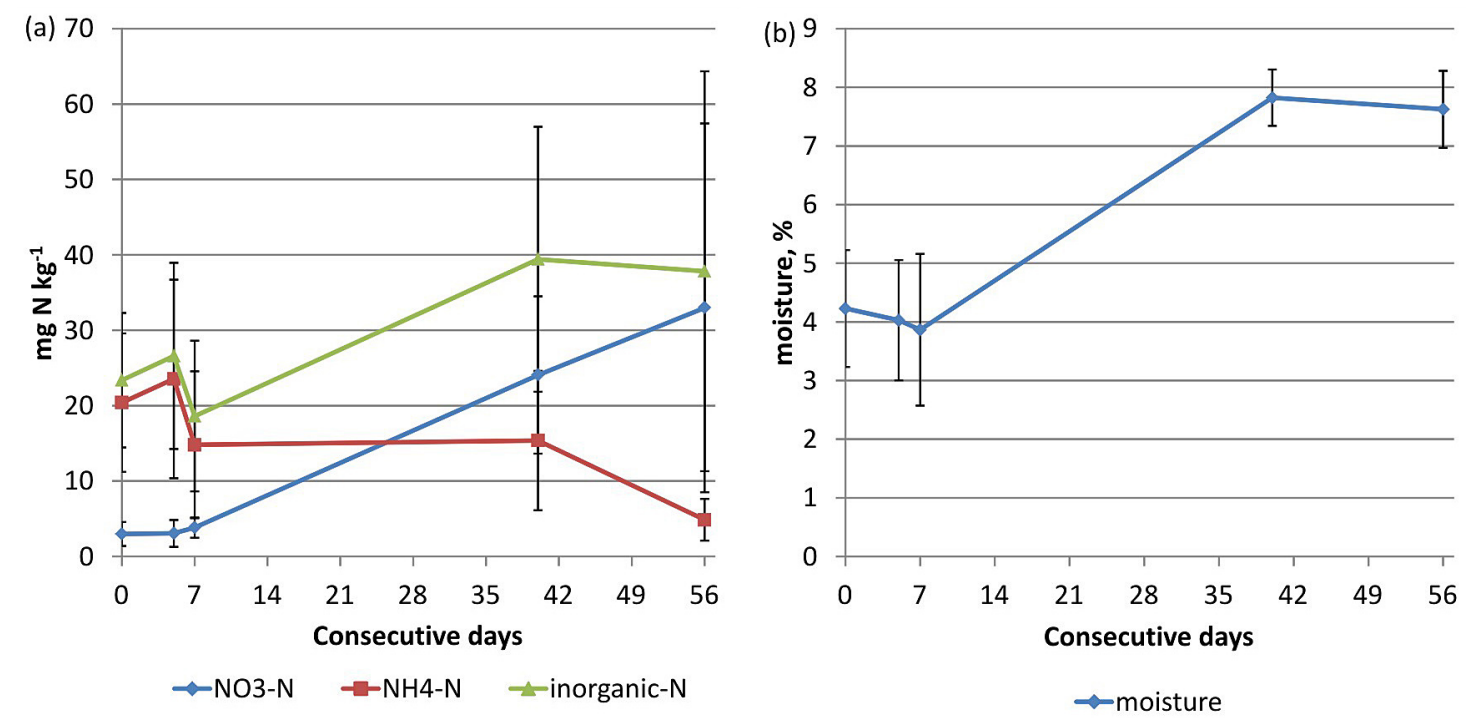

Figure 4. Changes in $\mathrm{NO}_{3}-\mathrm{N}, \mathrm{NH}_{4}-\mathrm{N}$ and inorganic-N content (a) and moisture (b) in soil treated with digestate in the studied field

[2011]. However, Riva et al. [2016] reported serious ammonia losses through emissions when digestate was applied at the surface. In the present study, even though discing do not mix fertilizer with soil thoroughly, the almost immediate incorporation of digestate to the soil coild impair the ammonia emissions.

The average $\mathrm{pH}$ of soil in the studied field was equal to $4.32 \pm 0.23$ and slightly increased during 56 days to $4.70 \pm 0.23$. The average soil EC at day 0 after addition of fertilizer amounted to $109.6 \pm 21.3 \mu \mathrm{S} \mathrm{cm}^{-1}$ and changed in the next 56 days to the value of $153.7 \pm 59.0 \mu \mathrm{S} \mathrm{cm}^{-1}$. The TN content at day 0 and at the end of study period (day 56) was similar $\left(0.9 \pm 0.7 \mathrm{~g} \mathrm{~N} \mathrm{~kg}^{-1}\right)$, while the SOC content just after digestate incorporation into the soil was equal to $7.9 \pm 0.62 \mathrm{~g} \mathrm{C} \mathrm{kg}^{-1}$ and after 56 days organic carbon content in soil reached the value of $8.2 \pm 0.7 \mathrm{~g} \mathrm{C} \mathrm{kg}^{-1}$; however. this difference was statistically insignificant ( $p>0.05$ ).

It is worth noting that 2015 was an extremely warm year, with very warm June, anomalously warm July, extremely warm August and anomalously warm September [IMWM, 2015]. The mean monthly temperatures measured by the weather station located at the Białystok University Technology were $17.7^{\circ} \mathrm{C}, 20.1^{\circ} \mathrm{C}, 23.2^{\circ} \mathrm{C}$ and $15.4^{\circ} \mathrm{C}$ in June, July, August and September, 
respectively. Summer of 2015 was characterized by higher mean temperature than the mean temperature from years 1951-2015, which was caused mainly by very high temperatures in July and extremely high temperatures in August. The maximum temperatures $\left(\mathrm{T}_{\max }\right)$ were higher by $70 \%$ than mean $\mathrm{T}_{\max }$ for years 1951-2015 [Sulikowska et al. 2016].

Year 2015 during vegetation period was dry, very dry and extremely dry in June, July, August and September [Kuchar et al. 2017]. The monthly precipitation recorded by the weather station at the Białystok University of Technology in June, July, August and September was $28 \mathrm{~mm}, 56 \mathrm{~mm}$, $5 \mathrm{~mm}$ and $33 \mathrm{~mm}$, respectively. In the study period, the mean daily temperatures in August ranged from $17.3^{\circ} \mathrm{C}$ to $29.1^{\circ} \mathrm{C}$ and a very low precipitation was recorded only in two days. September was colder, with mean daily temperatures from $10.7^{\circ} \mathrm{C}$ to $26.7^{\circ} \mathrm{C}$ and still rather low precipitation (Figure 5). These high temperatures and low precipitation were reflected in very low soil moisture. Higher precipitation in September resulted in an increase of soil moisture to $7.82 \pm 0.48 \%$. These very dry and warm conditions were favourable to the nitrification process, because it reaches the optimum at temperature ranges from $25^{\circ} \mathrm{C}$ in temperate climate to $35^{\circ} \mathrm{C}$ in tropical soils. Very dry conditions may partially impair the process, even though nitrifying bacteria are autotrophs producing nitrate in the presence of oxygen; hence, the nitrification occurs in well-aerated soils with the maximum rate of $\mathrm{NO}_{3}{ }^{-}$production when soil air contains $20 \%$ of oxygen, which is similar concentration to this in the atmospheric air, because - to some extent - the nitrification decreases in dry soil [Sahrawat 2008]. This is especially important in a changing climate in which hot summers are predicted to occur more often. Global warming increases the temperature extremes, mainly hot events, ranging from a single day or a few consecutive days (heat waves) even to monthly or season events. Although the annual precipitation is predicted to increase in high latitudes of Northern Hemisphere, the elevated evapotranspiration over the land may lead to more frequent and more intense periods of agricultural drought and overall low soil moisture in summer. At the same time, at daily to weekly scales, more intense individual storms are projected [IPCC 2013]. Such events may contribute to higher soil erosion rates and rapid leaching increasing the nitrogen losses from soil. Especially, nitrate leaching may partially exacerbate the advantages of digestate application to soil as fertilizer. Even though the nitrate concentration in the leachates from the soils fertilized with digestate was lower than that obtained from the soils treated with mineral fertilizer with the same $\mathrm{N}$ dosage, the nitrate leaching potential of biogas residues was similar to this of cattle slurry [Svoboda et al. 2013]. Thus, the digestate derived from AD processing of energy crops has a potential for substituting mineral fertilizers, but in the case of leaching potential it does not have an advantage over other organic fertilizers.

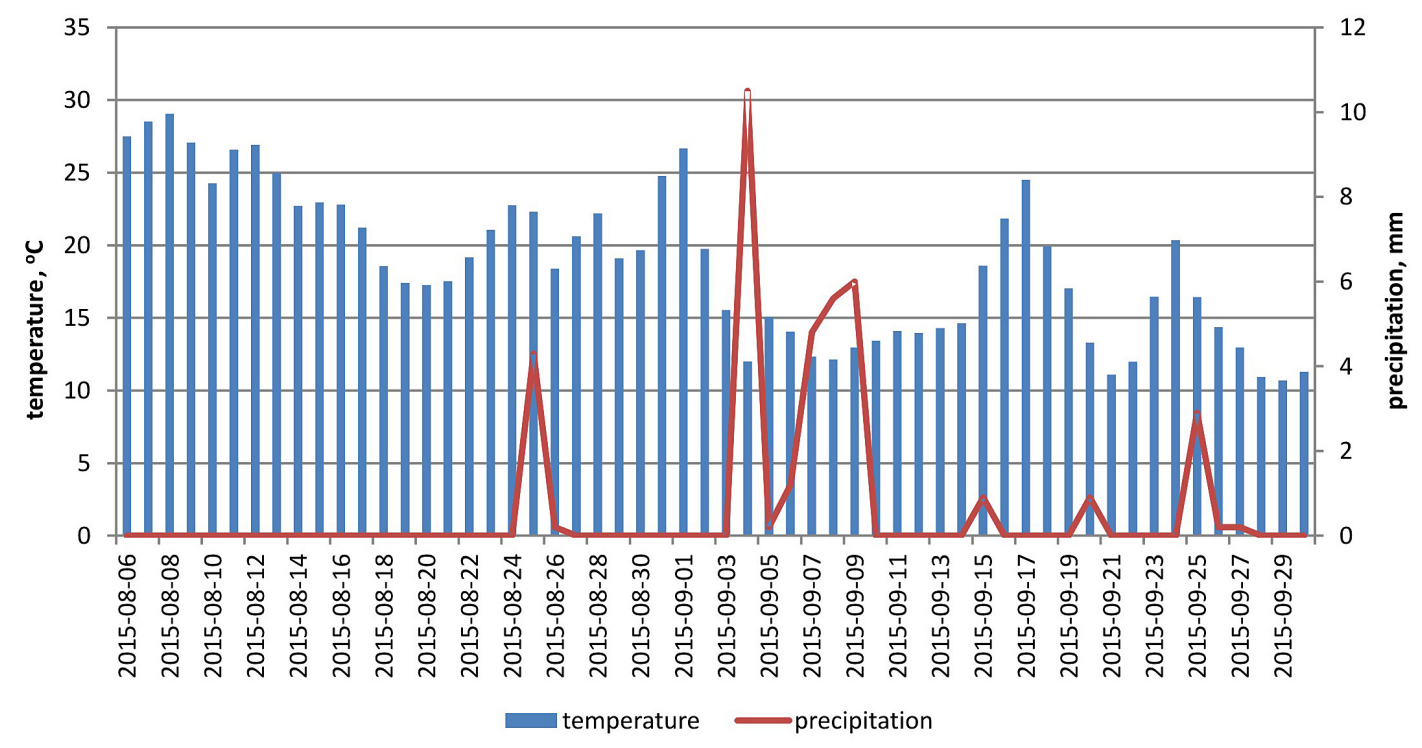

Figure 5. Daily temperatures and precipitation in study period recorded by the weather station located at the Białystok University of Technology 
Finally, it must be emphasized that the spatial variability of chemical properties in the studied soil was pronounced and, therefore, 10 samples were taken to establish inorganic- $\mathrm{N}$ dynamics. In the case of incubation, the variation among the replicate samples was lower; thus, only three replicates were used. Lack of sampling between 7 and 40 day after fertilization may also influence the observed pattern of soil $\mathrm{N}$ transformations; therefore. more frequent sampling campaign should be planned. However, it must be borne in mind that the sampling scheme should include the changes in soil moisture and air temperature, which are unavoidable under natural weather conditions.

\section{CONCLUSIONS}

The results of the study confirmed that the addition of the digestate obtained through anaerobic digestion of maize silage supplies the soil in ammonium-N, which is rapidly transformed to the nitrate form. This implies the management for field application of digestate should minimize the potential losses of nitrate, which may occur mainly during the late productive stage or after harvest. The overall pattern of $\mathrm{N}$ dynamics in the soil fertilized with the digestate was the same in the incubation experiment and in the field under the weather conditions of dry and hot summer, which is predicted to occur more often as a result of global warming. These conditions are favourable for the nitrification process and rapid increase of nitrate in soil may have a negative impact on surface and ground waters through elevated $\mathrm{NO}_{3}^{-}$leaching. Finally, the incubation experiment in laboratory conducted under controlled conditions, gives more reliable results with lower heterogeneity, which can be easily compared with the results from other studies.

\section{Acknowledgements}

This work was financially supported by Ministry of Science and Higher Education as a part of the project S/WBiIŚ/01/17.

\section{REFERENCES}

1. Alburquerque J.A., de la Fuente C., Bernal M.P. 2012. Chemical properties of anaerobic digestates affecting $\mathrm{C}$ and $\mathrm{N}$ dynamics in amended soils. Agriculture, Ecosystems \& Environment, 160, 15-22.
2. APHA 1999. Standard methods for the examination of water and waste water, 20th edition. American Public Health Association, Washington, DC, USA, 1268 pp.

3. Bernal M.P., Kirchmann H. 1992. Carbon and nitrogen mineralization and ammonia volatilization from fresh, aerobically and anaerobically treated pig manure during incubation. Biology \&. Fertility of Soils, 13, 135-141.

4. Cavalli D., Corti M., Baronchelli D., Bechini L., Gallina P.M. 2017. CO2 emissions and mineral nitrogen dynamics following application to soil of undigested liquid cattle manure and digestates. Geoderma, 308, 26-35.

5. de la Fuente C., Alburquerque J.A., Clemente R., Bernal M.P. 2013. Soil $\mathrm{C}$ and $\mathrm{N}$ mineralisation and agricultural value of the products of an anaerobic digestion system. Biology and Fertility of Soils, 49, 313-322.

6. Delin S., Stenberg B., Nyberg A., Brohede L. 2012. Potential methods for estimating nitrogen fertilizer value of organic residues. Soil Use and Management, 28, 283-291.

7. Gattinger A., Muller A., Haeni M., Skinner C., Fliessbach A., Buchmann N., Mäder P., Stolze M., Smith P., El-Hage Scilabba N., Niggli U. 2012. Enhanced top soil carbon stocks under organic farming. PNAS, 109, 44, 18226-18231.

8. Goberna M., Podmirseg S.M., Waldhube, S., Knapp B.A., Garcí, C., Insam H. 2011. Pathogenic bacteria and mineral $\mathrm{N}$ in soils following the land spreading of biogas digestates and fresh manure. Applied Soil Ecology, 49, 18-25.

9. Gómez-Brandón M., Fernández-Delgado Juárez M., Zangerle M., Insam H. 2016. Effects of digestate on soil chemical and microbiological properties: A comparative study with compost and vermicompost. Journal of Hazardous Materials, 302, 267-274.

10. Górniak A. 2000. Climate of the Podlaskie Voivodeship [in Polish]. IMGiW, Białystok.

11. IMWM 2015. Climate Monitoring Bulletin. Institute of Meteorology and Water Management. National Research Institute, Warsaw.

12. IPCC 2013. Climate Change 2013: The Physical Science Basis. Contribution of Working Group I to the Fifth Assessment Report of the Intergovernmental Panel on Climate Change [Stocker, T.F., D. Qin, G.-K. Plattner, M. Tignor, S.K. Allen, J. Boschung, A. Nauels, Y. Xia, V. Bex and P.M. Midgley (eds.)]. Cambridge University Press, Cambridge, United Kingdom and New York, NY, USA, 1535 pp.

13. Johansen A., Carter M.S., Jensen E.S, HauggardNielsen H., Ambus P. 2013. Effects of digestate from anaerobically digested cattle slurry and plant materials on soil microbial community and emission of CO2 and N2O. Applied Soil Ecology, 63, 36-44. 
14. Journal of Laws of 2007 No. 147 item 1033. Act of 10 July 2007 on fertilisers and fertilizing, 1-29.

15. Kucharek L., Iwański S., Diakowska E., Gąsiorek E. 2017. Assessment of meteorological drought in 2015 for north central part of Poland using hydrothermal coefficient (HTC) in the context of climate change [in Polish]. Infrastruktura i Ekologia Terenów Wiejskich, I/2/2017, 257-273.

16. Malerba A.D., Kaiser K., Tambone F., Adani F., Buscaroli A., Provenzano M.R. 2014. Hydrophilic and hydrophobic fractions of water-soluble organic matter in digestates obtained from different organic wastes. International Biodeterioration \& Biodegradation, 94, 73-78.

17. Möller K., Müller T. 2012. Effects of anaerobic digestion on digestate nutrient availability and crop growth: a review. Engineering in Life Science, 12, 1-16.

18. Myrold D.D., Posavatz N.R. 2007. Potential importance of bacteria and fungi in nitrate assimilation in soil. Soil Biology and Biochemistry, 39, 1737-1743.

19. Rigby H., Smith S.R. 2013. Nitrogen availability and indirect measurements of greenhouse gas emissions from aerobic and anaerobic biowaste digestates applied to agricultural soils. Waste Management, 33, 2641-2652.

20. Riva C., Orzi V., Carozzi M., Acutis M., Boccasile G., Lonati S., Tambone F., D'Imporzano G., Adani F. 2016. Short-term experiments in using digestate products as substitutes for mineral $(\mathrm{N})$ fertilizer: Agronomic performance, odours, and ammonia emission impacts. Science of the Total Environment, 547, 206-214.
21. Sahrawat K.L. 2008. Factors influencing nitrification in soils. Communications in Soil Science and Plant Analysis, 39, 1436-1446.

22. Schrama M., de Haan J.J., Kroonen M., Verstegen H., Van der Putten W.H. 2018. Crop yield gap and stability in organic and conventional farming systems. Agriculture, Ecosystems and Environment, 256, 123-130.

23. Smith S.R., Woods V., Evans T.D. 1998. Nitrate dynamics in biosolids-treated soils, II. Thermaltime models of the different nitrogen pools. Bioresource Technology, 66, 151-160.

24. Stockdale E.A., Shepherd M.A., Fortune S., Cuttle S.P. 2002. Soil fertility in organic farming systems - fundamentally different? Soil Use and Management, 18, 301-308.

25. Sulikowska A., Wypych A., Woszczek I. 2016. Wave of heat in summer 2015 and their circulation conditions [in Polish]. Badania Fizjograficzne. R. VII, Seria A, Geografia fizyczna, A67, 205-223.

26. Svoboda N., Taube F., Wienforth B., Kluß C., Kage H., Herrmann A. 2013. Nitrogen leaching losses after biogas residue application to maize. Soil \& Tillage Research, 130, 69-80.

27. Wysocka-Czubaszek A., Czubaszek R., Roj-Rojewski S., Banaszuk P. 2018. A comparative study of digestate and cattle slurry application on $\mathrm{N}$ dynamics in fertilized soils. Proceedings of 17th International Scientific Conference Engineering for Rural Development, 23-25.05.2018 Jelgava, Latvia, 1804-1809. 